\title{
Resistance of Nilaparvata lugens to Fenobucarb and Imidacloprid and Susceptibility to Neem Oil Insecticides
}

\author{
Danar Dono ${ }^{1 *}$, Neneng S. Widayani ${ }^{2}$, Safri Ishmayana ${ }^{3}$, Yusup Hidayat ${ }^{1}$, Fitri Widiantini' ${ }^{1}$, Ceppy Nasahi' \\ ${ }^{1}$ Department of Plant Pests and Diseases, Faculty of Agriculture, Universitas Padjadjaran, Bandung, Indonesia \\ ${ }^{2}$ Alumni of Magister Student in Department of Plant Pests and Diseases, Faculty of Agriculture Universitas Padjadjaran, Bandung, \\ Indonesia \\ ${ }^{3}$ Department of Chemistry, Faculty of Mathematics and Natural Sciences, Universitas Padjadjaran, Bandung, Indonesia
}

\section{ARTICLE INFO}

Article history:

Received January 19, 2020

Received in revised form December 18, 2021

Accepted January 4, 2022

KEYWORDS:

Resistance ratio,

detoxification,

enzyme,

botanical insecticide,

nerve poison,

Brown Plant Hopper

\begin{abstract}
This study aims to monitor and determine the level of resistance of $N$. lugens to fenobucarb and imidacloprid, to analyse of the specific activities of asetylcholinesterase, Glutation S-Transferase, esterase, and to determine sensitivity of resistant $N$. lugens to the neem oil. Resistance tests were conducted on a field population from Cipunagara, Subang, West Java, Indonesia, and a standard population originating from Banyuwangi, East Java, that was obtained from the Indonesian Center for Rice Research. Synthetic and neem Insecticides were applied using the leaf-stem dipping method. The resistance ratio obtained by comparing the $\mathrm{LC}_{50}$ value of the field population with the standard. The test insects were considered to be resistant to synthetic insecticide if they had a resistance ratio (RR) of more than 4 , indicated resistance if $R R \geq 1$, and susceptible to neem if has $R R<1$. The results of the research showed that the $N$. lugens population of Cipunagara indicated resistance to fenobucarb $(R R=2.43)$, while it was clearly resistance to imidacloprid $(R R=13.95)$. Specific activities of the acetylcholinesterase and Glutathione S-Transferase of the $N$. lugens Cipunagara populations were higher than the standard, while the esterase specific activity was lower. These two enzymes are responsible for the resistance of $N$. lugens to fenobucarb and imidacloprid. Nevertheless, the $N$. lugens population of Cipunagara was susceptible to neem $(R R<1)$ that never been reported before. Therefore, it is important to know the change in the sensitivity of the target and the metabolic pathway of the insecticide used to manage insect resistance.
\end{abstract}

\section{Introduction}

In general, intensive use of synthetic insecticides can cause the development of a resistant population of Nilaparvata lugens Stal. (Hemiptera: Delphacidae). Resistance to insecticides defined as 'a heritable change in the sensitivity of a pest population that is reflected in the repeated failure of an insecticide product to achieve the expected level of pests control when used according to the label recommendation doses for that pest species (Insecticides Resistance Action Committee (IRAC) 2013, 2021; Baehaki et al. 2016). Resistant insects are formed because of the selection process, which causes an increase in the resistant population through the development of the

\footnotetext{
* Corresponding Author

E-mail Address: danar.dono@unpad.ac.id
}

biochemical detoxification mechanism (Dono et al. 2010; Khan et al. 2020). Cases of Nilaparvata lugens resistance led to the banning of some insecticides for use with rice plants in 1986 and more recently in 2015 by the Indonesian government. The active ingredients prohibited are included in the group of organophosphates (24 active ingredients) and carbamate (carbaryl, methomyl and kartap hydrochloride). Suggest that insect resistance to insecticides is a common problem in many countries (Liu et al. 2005). Study resistance of $N$. lugens to insecticides in China and Bangladesh indicate that $N$. lugens has been resistance to several insecticides that are imidacloprid (resistance ratio, $\mathrm{RR}=2491.0$ 8078.5-fold), thiamethoxam ( $R R=303.6-1253.6$ fold), buprofezin ( $R R=175.7-365.1$-fold) and dinotefuran ( $R R=49.9-596.0$-fold), low to moderate levels of resistance to nitenpyram $(R R=12.1-67.3$ - 
fold) and sulfoxaflor ( $R R=3.8-25.5$-fold) (Datta et al. 2021). According to the latest record in Arthropod Pesticide Resistance Database (APRD), it have been reported that were 445 cases of $N$. lugens that were resistant to insecticides throughout the world (APRD 2021).

Insecticides with active ingredient of fenobucarb (carbamat) and imidacloprid (neonicotinoid) are registered in Indonesia to controlN. lugens(Directorate of Fertilizers and Pesticides 2016). Fenobucarb (carbamate) is an insecticide that inhibits the action of the enzyme Acetylcholinesterase (AChE) (Casida and Durkin 2013), while imidacloprid (neonicotinoid) has a neuroexcitatory effect and irreversibly blocks the acetylcholine receptor (Cox 2001; Tan et al. 2008).

Cases of $N$. lugens resistance to both insecticides have been widely reported. N. lugens from populations in Serang, Karawang, Subang, Indramayu, Purbalingga and Pasuruan (Indonesia) had resistance ratio (RR) values to imidacloprid of 4.8-108.1 times. The levels of resistance to fenobucarb were 6.6 in Indramayu, while in Karawang, Subang, Purbalingga and Pasuruan the RR values were 2.5-3.00 (Surahmat et al. 2016). The populations of Sukamandi and Juwirig were resistant to imidacloprid ( $R R=12.7, R R=7.0$ ), but susceptible to fenobucarb $(R R=1.8, R R=3.3)$ (Baehaki et al. 2016). Unfortunately, no information about biochemical mechanism of $N$. lugens resistance reported from these area of studies, besides never yet tested the botanical insecticide against the resistant insect that will be evaluated in this research. An effective handling of resistance involves the initial detection of problems, the combination of information on resistant insects, and determination of resistance ratio data, so that appropriate selection of insecticides can be made (Haque et al. 2002).

There are several strategies to manage N. lugens resistance, one of which is the rotation of the applied insecticides with those that have different modes of action (Hastutiek and Fitri 2002). The use of a broad spectrum of botanical insecticides with various modes of action, such as neem (Azadiracta indica) seed oil, is one alternative. Neem oil, which acts by hormonal disruption, can inhibit or delay the development of instars, disrupt the moulting process, and disrupt ovarian development (Suryaningsih and Hadisoeganda 2007; Pathak and Tiwari 2017). Based on this background, the study aims to 1) monitoring and determine the level of resistance of $N$. lugens from Cipunagara (Subang, West Java, Indonesia) to fenobucarb and imidacloprid, 2) to evaluates the specific enzyme activities of AChE, Glutation S-Transferase (GST) and esterase to determine the biochemical mechanism of $N$. lugens resistance, and 3 ) to determine sensitivity of resistant $N$. lugens to the botanical insecticide formulation of neem oil that never been studied before.

\section{Materials and Methods}

\subsection{Plants, Insects, and Insecticides}

The test insects used were $N$. lugens, which were obtained from Banyuwangi (the standard population) and Cipunagara (the field population). The standard population of $N$. lugens was obtained from the Indonesian Center for Rice Research (ICRR) and had been reared in a greenhouse for 35 generations without exposure to insecticides. The field population was taken from Padamulya Village, Cipunagara District, Subang Regency in July 2018. The rice plants used for the maintenance and testing of $N$. lugens were IR64 varieties.

The test insecticides used contained the active ingredient fenobucarb (BPMC) $500 \mathrm{gL}^{-1}$ in the form of an emulsifiable concentrate (EC) formulation, and imidacloprid $200 \mathrm{gL}^{-1}$ in the form of a soluble concentrate (SC). Fenobucarb has mode of action as acetylcholine inhibitor (class 1A: carbamat), while imidacloprid as Nicotinic acetylcholine receptor (nAChR) competitive modulators (class 4A: neonicotinoid) (Directorate of Fertilizers and Pesticides 2016; IRAC 2021). The botanical insecticide used was neem oil $500 \mathrm{gL}^{-1}$ in the form of an EC formulation (azadirachtin content $133.80 \pm 24.91$ $\mathrm{mgL}^{-1}$ ) (Dono et al. 2017). Five series of concentrations and controls were tested for each insecticide. Distilled water was mixed with an emulsifier (alkyl aryl polyglycol ether $\left.400 \mathrm{mg} . \mathrm{L}^{-1}\right)$ (Agristic $®$ ) at a concentration of 0.5 $\mathrm{ml.} \mathrm{L}^{-1}$ (Dono et al. 2010). The control N. lugens was treated only with distilled water with the addition of emulsifiers at the same concentration.

\subsection{Resistance Diagnosis}

Resistance diagnosis was conducted to detect the $N$. lugens of the Cipunagara population (field population) that were resistant to insecticides. From this population, 200 and $60 \mathrm{~N}$. lugens were taken as test insects and control respectively. The concentration of the insecticide tested was obtained from the $\mathrm{LC}_{95}$ of the Banyuwangi population (standard population). The tests were performed using the residual method (leaf dipping method) that will do as described in 
testing the $N$. lugens resistance level to the insecticide. Furthermore, the number of individuals that survived over the expected proportion (5\%) was calculated using a one-way Z test (Roush and Miller 1986) (Equation $1)$.

$$
Z=\frac{(s-n g)-0.5}{\sqrt{n g(1-g)}}
$$

Where:

$$
\begin{aligned}
\mathrm{S} & =\text { number of individuals which survive } \\
\mathrm{n} & =\text { sample size (namely } 200 \text { individuals) } \\
\mathrm{g} & =\text { percentage of individuals surviving } \\
& \text { expectations in standard strains }(0.05)
\end{aligned}
$$

Furthermore, the minimum number of individuals that survived to reach the significant level was calculated using Equation 2:

$$
\mathrm{s}=\mathrm{Z} \sqrt{(n g(1-g)}+n g+0.5 \quad \text { Eq. } 2
$$

\subsection{Testing of the Resistance Level of $\boldsymbol{N}$. lugens}

The $N$. lugens population from Cipunagara was exposed to fenobucarb and imidacloprid to determine its resistance level. The test used five levels of concentration and a control, which were repeated at least three times on $20 \mathrm{~N}$. lugens adult female test insects per repetition (Heong et al. 2011). The experiment employed the leaf dipping method (residual method in plants /contacts).

The method used refers to Surahmat et al. (2016) and was based on IRAC test method number 005 . Ten-twelve day old rice seedlings were cleaned with water to remove any soil. A total of 10 rice plants were wrapped in two sheets of wet tissue paper, put in a plastic tube $(5 \mathrm{~cm}$ in diameter, $5.5 \mathrm{~cm}$ in height), given a $1 \%(\mathrm{w} / \mathrm{v})$ water-agar solution 37 to cover the roots, and left until settled. Subsequently, all parts of the rice were dipped for 10 seconds into the test insecticide solution, dried for 15 minutes, and placed into a cylindrical plastic cage with a diameter of $5 \mathrm{~cm}$ and a height of $20 \mathrm{~cm}$. Then 10 adult $N$. lugens females were put into the cage. Mortality due to fenobucarb exposure was recorded at 24 and 48 hours, while for imidacloprid exposure was recorded at 24,48 , and 72 hours (IRAC 2013). The correlation of concentration and mortality data were analyzed using the Polo Plus Version 1.0 application to obtain the $\mathrm{LC}_{50}$ and $\mathrm{LC}_{95}$ values.
The value of the resistance level was calculated using Equation 3 (Georghiou 1962; Dono et al. 2010):

$$
\text { Resistance Ratio }(\mathrm{RR})=\frac{\mathrm{LC}_{50} \text { field population }}{\begin{array}{c}
\mathrm{LC}_{50} \text { standard } \\
\text { population }
\end{array}} \quad \text { Eq.3 }
$$

Insect populations originating from the field were considered to be resistant if they have an RR $\geq 4$ (Winteringham 1969; Surahmat et al. 2016), with indications that resistance had occurred if the $R R \geq 1$ (Surahmat et al. 2016).

\subsection{Biochemical N. lugens Resistance Mechanism Analysis}

Samples of adult female test insects were homogenized at low temperature with a concentration of $100 \mathrm{mg} / \mathrm{ml}$ in $0.1 \mathrm{M}$ phosphate buffer $\mathrm{pH} 7.0$ using Potter-Elvehjem homogenizer. This was used as the stock solution. The homogenate was centrifuged at $10,000 \mathrm{rpm}$ for 1 minute and the supernatant taken quickly so that the sediment did not dissolve again. For enzyme activity assay and protein determination, the stock solution was diluted when it was required. For control of enzyme activity assay, the sample were heated at $90^{\circ} \mathrm{C}$ for 10 minutes (Dono et al. 2010; Burden 2012).

\subsubsection{Asetilkolinesterase Activity (AChE) Assay}

The method for AChE assay was based on the method proposed by Ellman et al. (1961) and Dono et al. (2010). $200 \mu \mathrm{l}$ of the sample was added into a 10 $\mathrm{ml}$ test tube with $2 \mathrm{ml}$ of $0.1 \mathrm{M}$ phosphate buffer $\mathrm{pH}$ 7.5 and $150 \mu$ of $0.0011 \mathrm{M}$ DTNB in the same buffer. $100 \mu \mathrm{l}$ of insecticide with varying concentrations (buffer solution used as control) was then added to the tube and homogenized, followed by 10 minutes of incubation at $37^{\circ} \mathrm{C} .100 \mu \mathrm{l}$ of $0.0105 \mathrm{M}$ acetylcholine iodide was then added to the mixture. Subsequently, the mixture was incubated for 30 minutes at $37^{\circ} \mathrm{C}$. The absorbance was measured using a spectrophotometer at $\lambda=412 \mathrm{~nm}$. Enzyme activity was determined based on the absorbance increase at a wavelength of $412 \mathrm{~nm}$, and was defined as an increase in absorption of 0.001 units of absorbance above the control, per $\mathrm{ml}$ of the enzyme tested per minute. The activity is calculated using equation (5). The percentage inhibition of acetylcholinesterase activity by the insecticide was then calculated by Equation 4 .

$$
\% \text { Inhibition }=\frac{A_{o}-A_{1}}{A_{o}} \times 100 \%
$$


Where:

$\mathrm{A}_{0} \quad=$ control of acetyl cholinesterase (M substrate/minute/mg protein) control (without insecticide)

$\mathrm{A}_{1} \quad=$ acetyl cholinesterase activity with insecticide treatment

Furthermore, the relationship between insecticide concentration and inhibition of AChE enzyme activity was analyzed using probit analysis Polo Plus Version 1.0. From this relationship, $\mathrm{IC}_{50}$ (inhibition concentration at $50 \%$ ) was obtained, which showed a $50 \%$ reduction in AChE activity.

\subsubsection{Esterase Activity Assay}

The esterase activity was measured using $\alpha$-naphthyl acetate as substrate (Yu et al. 2003; Dono et al. 2010). $0.5 \mathrm{ml}$ of $0.1 \mathrm{M}$ phosphate buffer solution $\mathrm{pH} 7.0$, and then $15 \mu \mathrm{l} \alpha$-naphthyl acetate $0.02 \mathrm{M}$ (dissolved in methanol) and $2 \mathrm{ml}$ fast blue solution $0.25 \mathrm{mg} / \mathrm{ml}$ in distilled water was then added to $50 \mu$ of the sample. The mixture was then incubated at $37^{\circ} \mathrm{C}$ for 30 minutes and the absorption measured at $\lambda=490 \mathrm{~nm}$ and used to calculate the activity of the enzyme. As a control, the same sample, which had been heated at a temperature of $90^{\circ} \mathrm{C}$ for 10 minutes and centrifuged, was used. Enzyme activity was calculated using Equation (5). The enzyme activity was determined based on increased absorbance at $490 \mathrm{~nm}$ and was defined as an increase in absorption of 0.001 units of absorbance above the control, per ml of the enzyme tested per minute.

$$
\mathrm{AU}=\frac{\mathrm{As}-\mathrm{Ak}}{0.001 \times \mathrm{ti} \times \mathrm{Ve}}
$$

Where:

$$
\begin{aligned}
\mathrm{AU} & =\text { activities Unit } \\
\mathrm{As} & =\text { absorption of samples tested } \\
\mathrm{Ak} & =\text { aontrol absorption (Boiled samples) } \\
\mathrm{ti} & =\text { incubation time }(30 \text { minutes }) \\
\mathrm{Ve} & =\text { volume of enzyme tested: AchE }(0.2 \mathrm{ml}), \\
& \text { esterase }(0.05 \mathrm{ml}) \text { and GST }(0.02 \mathrm{ml})
\end{aligned}
$$

\subsubsection{Glutathione S-Transferase Activity Assay}

Glutathione S-Transferase activity used a 1-chloro2,4-dinitrobenzene (CDNB) as substrate. $0.86 \mathrm{ml}$ of $0.1 \mathrm{M}$ phosphate buffer $\mathrm{pH} 6.5,20 \mu$ l homogenate, $100 \mu \mathrm{l} 10 \mathrm{mM}$ glutathione in $\mathrm{pH}$ buffer 6.5 , and $10 \mu \mathrm{l}$ $1 \mathrm{mM}$ CDNB (in ethanol) were mixed in a test tube and incubated at $37^{\circ} \mathrm{C}$. Next, light absorption was measured by a spectrophotometer at $\lambda=340 \mathrm{~nm}$ and enzyme activity calculated using Equation (5). This was determined based on the increased absorbance at 340 $\mathrm{nm}$ and defined as an increase in absorption of 0.001 units of absorbance above the control, per $\mathrm{ml}$ of the enzyme tested per minute (Habig et al. 1974; Dono et al. 2010).

\subsection{Testing of $N$. lugens Susceptibility to Botanical Insecticide}

The N. lugens populations from Cipunagara and Banyuwangi were tested for their susceptibility to neem oil insecticide (formulation $50 \mathrm{EC}$ ). The experiment used the food dipping method (residual method on plants), as explained in the testing of the level of fenobucarb and imidacloprid insecticide resistance. In the susceptibility testing of $N$. lugens to neem oil insecticide, nymph $4^{\text {th }}$ instar was used, with observations of death made at 24-hour intervals for 10 days. The data were analyzed using the Polo Plus Version 1.0 program to obtain the $\mathrm{LC}_{50}$ and $\mathrm{LC}_{95}$ values. In this susceptibility test, a resistance ratio (RR) was used as an indicator for insect susceptibility to neem oil insecticide. If $R R<1$, this means that the insects are sensitive to the insecticide (Dono et al. 2014).

\section{Results}

\subsection{Detection and Resistance Level 3.1.1. Resistance Detection}

Resistance diagnosis was performed as the first step to find $N$. lugens resistance from the Cipunagara population. The proportion of individuals that survived after the application of fenobucarb (carbamate) and imidacloprid (neonicotinoid) was 0.0786 and 0.1419 respectively (Table 1 ). Both figures are greater than the minimum proportion of surviving individuals, which is 0.0778 . This indicates that $N$. lugens from Cipunagara has developed resistance to fenobucarb and imidacloprid. Therefore, further investigation of the resistance level is needed to determine the resistance ratio (RR) against the test insecticide.

\subsubsection{Level of Resistance}

The results of the fenobucarb and imidacloprid insecticide toxicity tests indicated a relationship between the concentration of insecticide and the mortality of the insects. The treatment with fenobucarb insecticide of the $N$. lugens population from Cipunagara (the field) showed that the $\mathrm{LC}_{50}$ 
and $\mathrm{LC}_{95}$ values were $0.85 \mathrm{ml} / \mathrm{L}$ and $2.73 \mathrm{ml} / \mathrm{L}$ respectively. These toxicity value were higher than for the Banyuwangi population (standard) $\left(\mathrm{LC}_{50} 0.35\right.$ $\mathrm{ml} / \mathrm{L}$ and $\mathrm{LC}_{95} 2.01 \mathrm{ml} / \mathrm{L}$ ). The results of the toxicity test of imidacloprid insecticides on N. lugens from the Cipunagara population (field) showed that this insecticide had $\mathrm{LC}_{50}$ and $\mathrm{LC}_{95}$ value of $7.95 \mathrm{ml} / \mathrm{L}$ and $54.11 \mathrm{ml} / \mathrm{L}$ respectively. The toxicity of imidacloprid insecticides on the $N$. lugens population from Banyuwangi (standard) was much lower, namely $0.57 \mathrm{ml} / \mathrm{L}$ and $4.07 \mathrm{ml} / \mathrm{L}$ for $\mathrm{LC}_{50}$ and $\mathrm{LC}_{95}$ respectively (Table 2).

Based on the calculation of the resistance ratio, the population of Cipunagara was already resistant to imidacloprid insecticides, with a ratio of 13.95 , and it has also showed indications of resistance to fenobucarb insecticides, with a resistance ratio of 2.43 (Table 2 ). The high resistance ratio to imidacloprid was probably caused by the intensive use of this insecticide by farmers in the sampling location. The low level of resistance to fenobucarb was because farmers rarely used this insecticide. They usually rotate insecticides if any are found to be ineffective.

\subsection{Analysis of Enzyme Activity}

\subsubsection{Acetylcholinesterase Activity Analysis}

The activity of the acetylcholinesterase enzyme (AChE) was tested to observe the effect of fenobucarb (carbamate) insecticide on the activity of the AChE

Table 1. Proportion of survival of $N$. lugens after treatment with $\mathrm{LC}_{95}$ of the Banyuwangi standard population

Population Insecticides Proportion of individuals
surviving in $\mathrm{LC}_{95}$ insecticide treatment

\begin{tabular}{lll}
\hline $\begin{array}{l}\text { N. lugens } \\
\text { population of } \\
\text { Cipunagara }\end{array}$ & Fenobucarb & 0.0786 \\
\cline { 2 - 2 } & Imidakloprid & 0.1419
\end{tabular}

Significantly different from the expectation at the 95\% real level (the minimum proportion to reach the real level is $\geq 0.0778$ ) enzyme and its resistance to the insecticide. The test results showed that the activity of the AChE from the Cipunagara population was higher than that of the Banyuwangi population, at 4.67 and 2.76 units/ mg respectively (Figure 1 ).

When fenobucarb was applied, AChE-specific activity decreased in line with the increasing concentration of the insecticide used. The linear regression between insecticide concentration and enzyme specific activity is presented by equation $\mathrm{y}$ $=-5.5486 \mathrm{x}+3.4275$ and $\mathrm{y}=-0.9254 \mathrm{x}+5.7858$, for AChE-specific activity from the Banyuwangi and Cipunagara populations respectively. The correlation coefficient in both populations was $r=0.98$, which indicates a very strong relationship between the insecticides inhibition and enzyme activity (Figure 1). The decrease in enzyme activity is also shown by the inhibition of the AChE by the insecticides (Figure 2).

The effect of the fenobucarb insecticide on the inhibition activity of $\mathrm{AChE}$ showed that the resistance level of $N$. lugens to the fenobucarb insecticide was related to the insensitivity of the AChE enzyme. The level of AChE enzyme insensitivity of the $N$. lugens from the Cipunagara (field) population to fenobucarb was 2.61 times that of Banyuwangi (standard) population) (Table 3 ). This value of insensitivity of the enzyme was similar to the level resistance to fenobucarb (Table 2), which indicates that the main mechanism of fenobucarb insecticide resistance was related to the $\mathrm{AChE}$.

\subsubsection{Esterase Activity}

An esterase enzyme activity test was conducted to determine its role as one of the detoxification enzymes of $N$. lugens. The enzyme test results show that the esterase-specific activity in the Banyuwangi population (standard) was higher than that of the Cipunagara (field) population. Specific esterase activity from the $N$. lugens population of Banyuwangi was 187.20 units/mg, while for that of Cipunagara it was 168.41 units/mg. The difference

Table 2. The resistance ratio of $500 \mathrm{~g} / \mathrm{L}$ fenobukarb insecticide and $200 \mathrm{~g} / \mathrm{L}$ imidacloprid against $N$. lugens originated from Cipunagara population (field) and Banyuwangi (standard)

\begin{tabular}{lllllllll}
\hline Insectiside & Population & $\mathrm{a} \pm \mathrm{SE}$ & $\mathrm{b} \pm \mathrm{SE}$ & $\mathrm{LC}_{50}$ & $\mathrm{Cl}_{95 \%}$ & $\mathrm{LC}_{95}$ & $\mathrm{Cl}_{95 \%}$ & $\mathrm{RR}$ \\
\hline Fenobucarb & Banyuwangi & $0.96 \pm 0.12$ & $2.12 \pm 0.21$ & 0.35 & $0.29-0.42$ & 2.10 & $1.52-3.32$ & 2.43 \\
(carbamat) & Cipunagara & $0.23 \pm 0.09$ & $3.24 \pm 0.32$ & 0.85 & $0.74-0.96$ & 2.73 & $2.22-3.64$ & \\
\hline Imidacloprid & Banyuwangi & $0.47 \pm 0.10$ & $1.92 \pm 0.18$ & 0.57 & $0.46-0.70$ & 4.07 & $2.84-6.71$ & 13.96 \\
(neonicotinoid) & Cipunagara & $-1.78 \pm 0.21$ & $1.98 \pm 0.19$ & 7.95 & $6.45-9.72$ & 54.11 & $38.41-87.49$ & \\
\hline
\end{tabular}

a: intercept, b: slope, SE: standard error, LC: lethal concentration (ml/l), CI: confidence interval, RR: resistance 


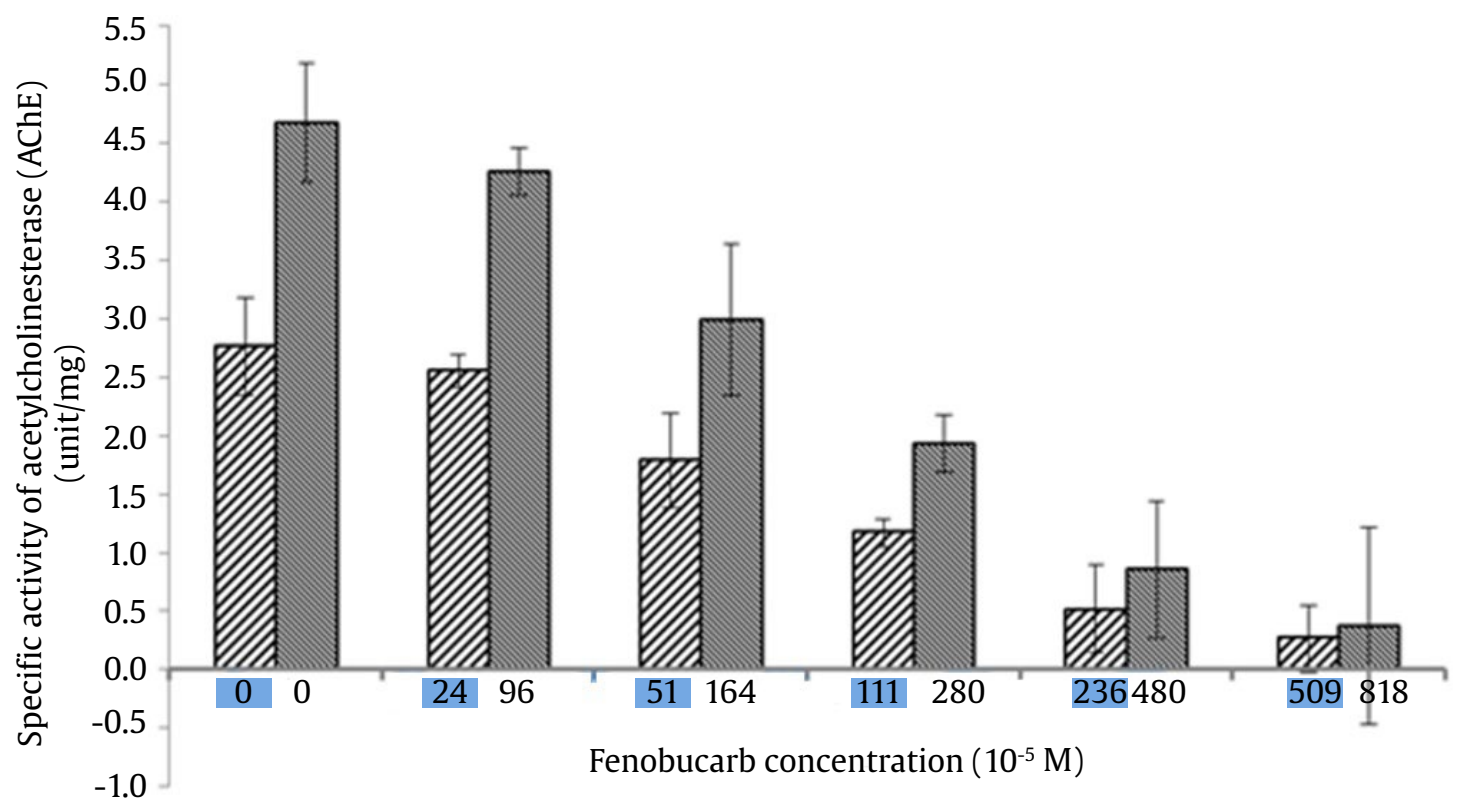

N. lugens population of Bayuwangi N. lugens population of Cipunagara

Figure 1. Specific activity of N. lugens AChE of Banyuwangi and Cipunagara population

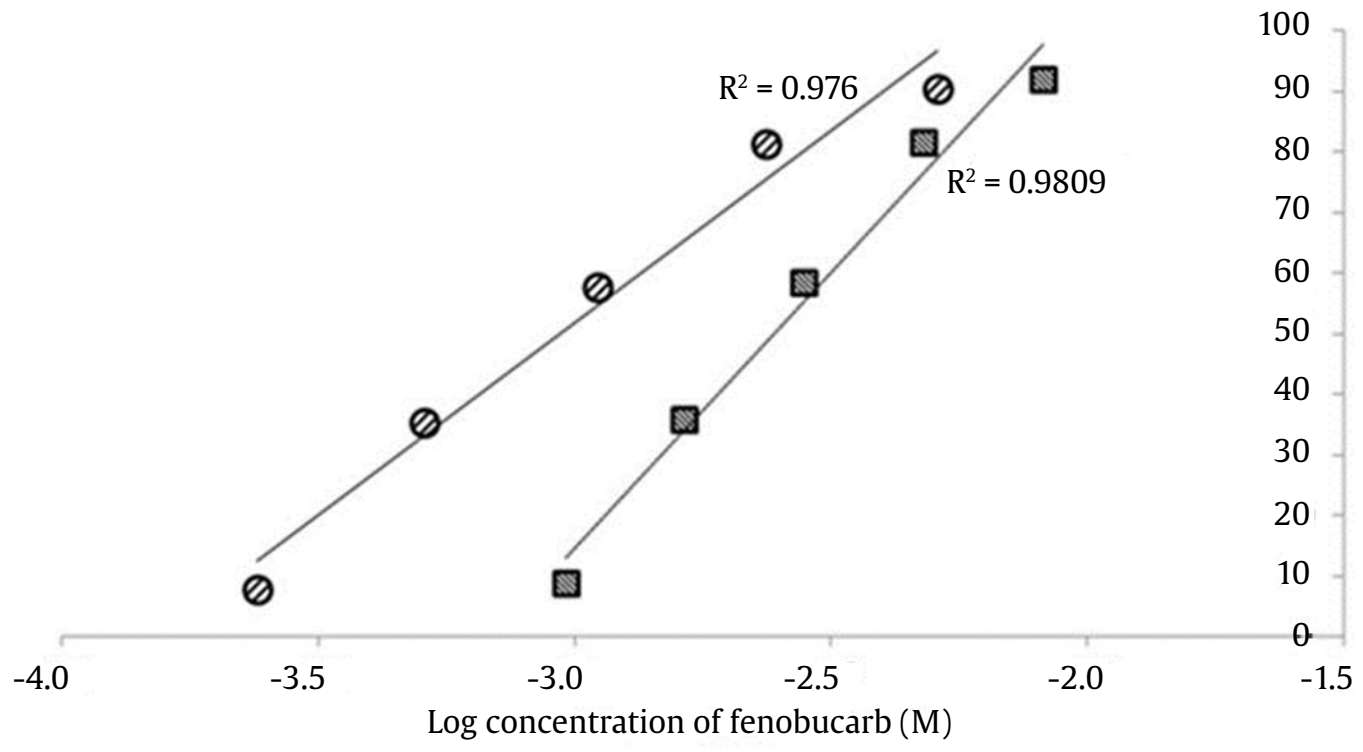

Figure 2. Inhibition of AChE by fenobucarb

Table 3. Acetylcholinesterase (AChE) enzyme susceptibility level N. lugens population of Banyuwangi and Cipunagara against fenobucarb.

\begin{tabular}{|c|c|c|c|c|c|c|c|}
\hline Population & $\mathrm{a} \pm \mathrm{SE}$ & $\mathrm{b} \pm \mathrm{SE}$ & $\mathrm{IC}_{50}\left(10^{-5} \mathrm{M}\right)$ & $\mathrm{CI}_{95 \%}$ & $\mathrm{IC}_{95}\left(10^{-5} \mathrm{M}\right)$ & $\mathrm{CI}_{95 \%}$ & IR \\
\hline $\begin{array}{l}\text { Banyuwangi } \\
\text { (standard) }\end{array}$ & $-3.83 \pm 0.32$ & $1.95 \pm 0.15$ & 91.57 & $68.98-119.45$ & 636.50 & $402.56-1353.49$ & 2.61 \\
\hline $\begin{array}{l}\text { Cipunagara } \\
\text { (field) }\end{array}$ & $-6.89 \pm 0.55$ & $2.89 \pm 0.23$ & 239.20 & $215.14-264.88$ & 883.64 & $731.50-1132.57$ & \\
\hline
\end{tabular}


in esterase enzyme specific activity between the two populations was 18.79 units/mg (Figure 3). That was indicated that esterase enzyme did not play in role of $N$. lugens resistance to fenobucarb. May be $N$. lugens develop another biochemical mechanism of resistance to this insecticide. The results show that the differences in esterase activity between the two populations cannot be used to explain the differences in the level of resistance of $N$. lugens to fenobucarb.

\subsubsection{Activity of the Glutathione S-Transferase}

Glutathione S-transferase (GST) activity was tested to determine the role of the enzyme in the resistance of $N$. lugens to insecticide. The test result of the specific GST enzyme activity in the $N$. lugens population from Cipunagara (field) was 1010.02 units $/ \mathrm{mg}$, higher than the specific activity of the GST N. lugens population of Banyuwangi (standard) (909.10 units/mg). The difference in GST-specific activity between the two populations was 100.92 units/mg (Figure 4). The results of the GST specific activity test show that GST was one of the resistance mechanisms that occurred in the $N$. lugens of the Cipunagara population.

\subsection{N. Iugens Susceptibility to Neem Oil Insecticide}

The results of the toxicity test of the neem oil insecticide using the leaf-stem dipping method gave $\mathrm{LC}_{50}$ values of $3.68 \mathrm{ml} / \mathrm{L}$ and $3.61 \mathrm{ml} / \mathrm{L}$ against the $N$. lugens populations of Banyuwangi and Cipunagara. The results of the resistance ratios indicate that the

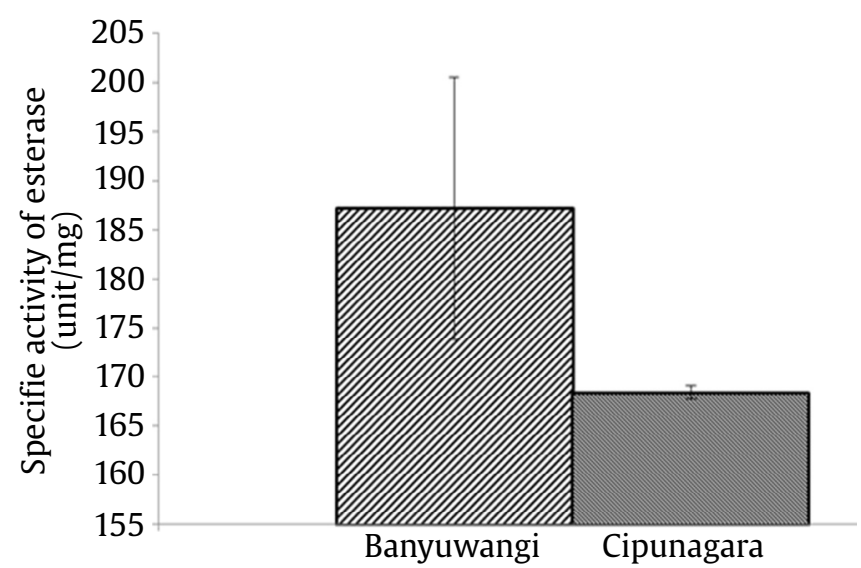

Figure 3. The specific activity of $N$. lugens esterase of Banyuwangi and Cipunagara population
$N$. lugens Cipunagara population is susceptible to neem insecticide, with a resistance ratio of $<1$ (Table 4).

\section{Discussion}

In many countries indicates that Intensive using of insecticide causes insect resistance. Study resistance of $N$. lugens to insecticides in China indicate that $N$. lugens has develop high levels of resistance to imidacloprid (resistance ratio, $\mathrm{RR}=2491.0$ - 8078.5-fold), while in Bangladesh 3680.1 - 4430.8-fold) because of intensive using of insecticides (Datta et al. 2021). Differences in the toxicity values of insecticide can be caused by the excretion and metabolic rate (Park et al. 1991). The $N$. lugens population of Ciasem and Sukamandi, Subang Regency is still susceptible to fenobucarb insecticides, with resistance ratios of 2.7 and 1.8 (Baehaki et al. 2016; Surahmat et al. 2016). The N. lugens population of Cipunagara was resistant to imidacloprid insecticide, which is virtually in line with the report of Baehaki et al. (2016), that the population of Sukamandi is resistant, with a ratio of 12.7. Increased resistance due to exposure to imidacloprid insecticides can occur if continuous selection is carried out (Zhang et al. 2014). Selection using imidacloprid causes the resistance ratio of $N$. lugens to increase by 11.35 times after 25 generations, and 14 times after 27 generations (Zewen et al. 2003; Wang et al. 2008).

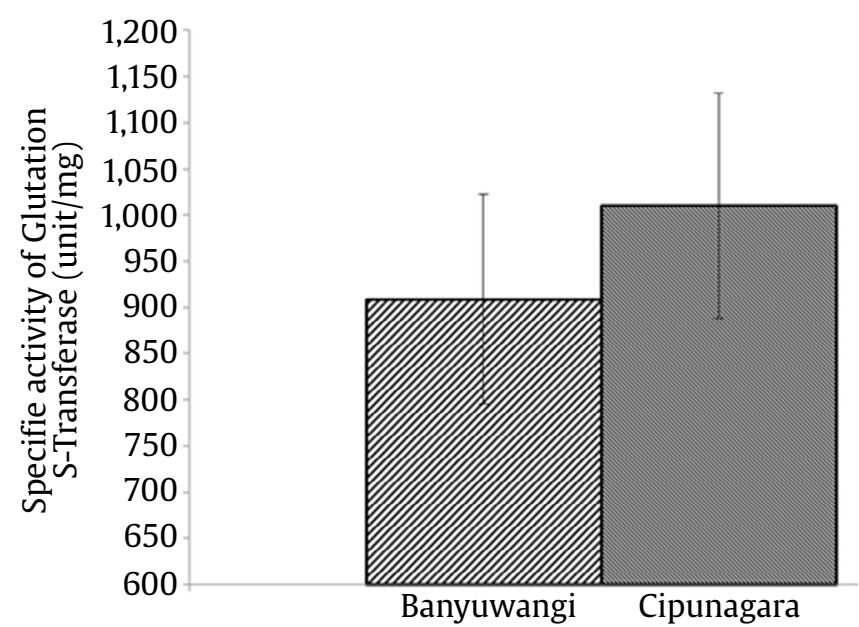

Figure 4. Specific activity of Glutathione S-Transferase in $N$. lugens population of Banyuwangi and Cipunagara 
Table 4. Susceptibility of $N$. lugens to neem oil insecticides

\begin{tabular}{lccccccc}
\hline Population & $\mathrm{a} \pm \mathrm{SE}$ & $\mathrm{b} \pm \mathrm{SE}$ & $\mathrm{LC}_{50}(\mathrm{ml} / \mathrm{l})$ & $\mathrm{Cl}_{95 \%}$ & $\mathrm{LC}_{95}(\mathrm{ml} / \mathrm{l})$ & $\mathrm{Cl}_{95 \%}$ & $\mathrm{RR}$ \\
\hline $\begin{array}{l}\text { Banyuwangi } \\
\text { (standard) }\end{array}$ & $-3.48 \pm 0.37$ & $3.79 \pm 0.38$ & 8.31 & $7.48-9.19$ & 22.56 & $18.78-29.30$ & \\
$\begin{array}{l}\text { Cipunagara } \\
\text { (field) }\end{array}$ & $-3.81 \pm 0.39$ & $4.17 \pm 0.41$ & 8.19 & $7.43-9.01$ & 20.32 & $17.23-25.59$ & 0.99 \\
\hline
\end{tabular}

a: intercept, b: slope (slope), SE: standard error, LC: lethal concentration (ml/l), CI: confidence interval, RR: resistance ratio

However, if the selection is stopped, this can cause a rapid decline in resistance, from 759 times to 114 times after 17 generations, until it finally stabilizes, but will increase again when selection is continued (Wang et al. 2009). Insect migration also significantly increases the level of resistance, because of the use of imidacloprid extensively and intensively in the field (Wang et al. 2008). Similar result showed by research of Diptaningsari et al. (2020) that is continuous selections with imidacloprid during five generations of selection increased the resistance ratio (RR) from 46.20-fold to 150.39 -fold. The resistance will be decrease if the selection pressure removed. Therefore, the unstable resistance insect can be managed by using insecticide with different mode of action.

AChE acts as a terminator in the transmission of impulses at the cholinergic synapse by hydrolyzing the neurotransmitter acetylcholine (ACh) (Dvir et al. 2010). Molecule target of inhibition of insecticide Carbamat group like fenobucarb is AChE (IRAC 2013, 2021). The values of asetylcholinesterase (AChE) insensitivity and fenobucarb resistance level are almost the similar (Tables 2 and 3). This indicates that the main mechanism for fenobucarb insecticide resistance is possibly in the insensitivity of AChE (Yoo et al. 2002; Toumi et al. 2016). According to study with chlorpyrifosoxon treatment showed that AChE activity of earwigs collected from conventional practice higher than in organic and IPM orchards (Navenant et. al. 2019). This indicating the insect from organic and IPM ochard were more sensitive than from conventional ones. AChE activity in resistant strains is higher than susceptible strains (Taşkin et al. 2007). It has been shown that the $N$. lugens population from Cipunagara (field) had AChE enzyme insensitivity 2.67 times greater than that of the N. lugens from Banyuwangi (standard).

Esterase activity can be associated with insect resistance. It can be detected using a substrate such as the original ester; for example, $\alpha$ - or $\beta$-naphthyl acetate. Resistance can be associated with an increase or decrease in naphthyl esterase activity (Devonshire 1991). Naphthyl esterase is a product formed from the reaction of $\alpha$-naphthyl acetate substrates, an enzyme source, and fast blue dye (used in this study). In Asperen's (1962) study, diazo blue-sodium lauryl sulphate was used to estimate the formation of naphthyl products. The use of insecticides is strongly correlated with increased naphthyl esterase activity (Taşkin et al. 2007). Based on this explanation, the esterase-specific activity in the $N$. lugens of the Cipunagara population should be higher than that of Banyuwangi (standard). However, in this study, the N. lugens field population did not show higher esterase-specific activity than standard.

Increased esterase activity does not always correlate with resistance status (Siegfried and Scott 1992). Differences in enzyme activity are likely to occur because of by differences in the genes in each population (Tarwotjo and Rahadian 2018). There is no correlation between changes in esterase activity between strains with imidacloprid resistance (Wang et al. 2009). Significantly lower levels of ali-esterase activity have not been found to be associated with carbamate resistance in Culex tarsalis (Plapp et al. 1961). The absence of the role of specific esterase enzymes in fenobucarb and imidacloprid insecticide resistance may also be caused by the development of other enzyme detoxification systems in the $N$. lugens population of Cipunagara. The main route of carbamate insecticide metabolism in animals is oxidative and is generally associated with the MFO enzyme (Futuko 1990). In addition, increased monooxygenase cytochrome P450 activity is the main mechanism of imidacloprid resistance in insects (Zewen et al. 2003; Wang et al. 2009; Puinean et al. 2010).

The GST activity of the $N$. lugens population of Cipunagara (field) was higher than that of Banyuwangi (standard). It was found that GST acts as one of the mechanisms of $N$. lugens resistance to fenobucarb (carbamates) and imidacloprid (neonicotinoid) insecticides. Increased GST activity has been associated with resistance to several major classes of insecticide and is associated with an increase in the number of one or more GSTs (Vontas et al. 2001; Nan-nan et al. 
2006; Datta and Banik 2021). Moreover, Insects can be resistant because of selection toward of insect having effective detoxification mechanism. The difference may be because the samples tested develop a different detoxification system when exposed to different insecticides (Dono et al. 2010). This indicates that in a population exposed to different insecticides, organisms will develop different detoxification systems. In the N. lugens population of Cipunagara, one detoxification mechanism that contributes to the resistance to insecticides is GST enzyme activity. The result of resistance study in China and Bangladesh indicate that an increase GST activities and other detoxification enzymes (EST and P450) were found in multiple-resistant FY19 field population (Datta et al. 2021). GST is induced by neonicotinoid insecticide (Smina et al. 2016). Anopheles stephensi, which has been resistant to deltamethrin (pyrethroid), DDT (Dichloro-Diphenyl-Trichloroethane) and propoxur (carbamate) shows high GST activity (Sanil et al. 2014). Hight activity of GST also indicated in Aphis gossypii and Aphis spiraecola populations against Imidacloprid, Dimethoate, Acephate, Quinalphos, Chlorpiriphos, Spinosad, and Thiamethoaxam (George et al. 2019). High GST activity in providing resistance by $N$. lugens is a result of protecting tissues from oxidative damage (Vontas et al. 2001; Maran et al. 2010). Therefore, study of sensitivity change of insecticide molecule target and activity of detoxification enzyme are important in strategy to control of insect resistance.

The results of the insecticide susceptibility test of the $N$. lugens population of Cipunagara against neem oil showed an RR value of $<1$ (Table 4). The RR values indicate that the $N$. lugens of the Cipunagara population (field) are still susceptible to the insecticides. This result shows that an insecticide which works with a different mechanism to the insecticide applied can be used as a solution for handling resistance to certain insecticides. In this study, neem oil insecticides can be used on the $N$. lugens population of Cipunagara against imidacloprid (neonicotinoid) and fenobucarb (carbamate) insecticides. Neem plays a role in resistance management because it can reduce the rate of detoxification enzymes, making the insecticide more effective (Lowery and Smirle 2000; Mordue (Luntz) and Nisbet 2000). Besides causing growth disruption (Govindachari et al. 2000), neem oil can disrupt the central nervous system, repel insects and inhibit feed (Mordue et al. 1998; Mordue (Luntz) and Nisbet 2000; Mardiningsih et al. 2010; Qiao et al. 2014). Principally, other botanical insecticides that have different action mechanisms or different modes of detoxification to the insecticides applied can be used to manage resistant populations. Plant extract may be used as an insecticide for controlling insect resistance, such as the bufadienolides group (i.e. daigremontianins, $\mathrm{LD}_{50}$ $0.9 \mu \mathrm{g} / \mathrm{g}$ of diet), extracted from Kalanchoe pinnata and K. daigremontiana (Hidayat et al. 2014). Further research is needed to explore the potency of botanicals insecticides to control of insect resistance to synthetic insecticides.

In conclusions, the $N$. lugens population of Cipunagara(field) was indicated resistant to fenobucarb insecticide (resistance ratio $(\mathrm{RR}=2.43$ ) but resistant to imidacloprid insecticides $(R R=13.95)$. The insensitive of the acetylcholinesterase (ACHE) of the $N$. lugens field population was considered to play in resistance the insect to the fenobucarb, and Glutathione S-Transferase (GST) against fenobucarb and imidacloprid. Thus, it is important to know the change of target sensitivity and metabolism pathway of insecticide in management resistance of insect. The field population of $N$. lugens is susceptible to neem oil insecticides, with a value of $\mathrm{RR}<1\left(\mathrm{LC}_{50} 3.61 \mathrm{ml} / \mathrm{l}\right)$. Neem oil could be used as a solution for $N$. lugens resistance management against fenobucarb and imidacloprid insecticides.

\section{Conflicts of Interest}

All author writers who play a role in research, funding, and writing this manuscript actually state that they have no conflict of interest.

\section{Acknowledgements}

The research was funded by Universitas Padjadjaran internal grant program (HIU) through the Competency Research Scheme (Number 014/UN6/EP/PL/20182019).

\section{References}

[APRD] Arthropod Pesticide Resistance Database., 2021. Arthropod Pesticide Resistance Database. Available online: https://www. pesticideresistance. org/search. php. [Date accessed:13 September 2021]

Asperen's, K.V.A.N., 1962. A study of housefly esterases by means of a sensitive colorimetric. J. Insect Physiol. 8, 401-416. https://doi.org/10.1016/00221910(62)90074-4

Baehaki, S.E., Iswanti, E.H., Munawar, D., 2016. Resistance of brown planthopper to insecticides circulating in rice production centers. Penenlitian Pertan. Tanam. pangan. 35, 99-108. ttps://doi.org/10.21082/jpptp. v35n2.2016.p99-108 
Burden, D.W., 2012. Guide to the disruption of biological samples. Random Primers. 12, 1-25.

Casida, J.E., Durkin, K.A., 2013. Neuroactive insecticides: targets, selectivity, resistance, and secondary effects. Annu. Rev. Entomol. 58, 99-117. https://doi. org/10.1146/annurev-ento-120811-153645

Cox, C., 2001. Imidacloprid. Jorunal Pestic. Reform. 21, 15-21. https://doi.org/10.1098/ rstb.2000.0775

Datta, J., Banik, S.C., 2021. Insecticide resistance in the brown planthopper, Nilaparvata lugens (Stål): mechanisms and status in Asian Countries. J. Entomol. Res. Soc. 23, 225-238. https://doi.org/10.51963/jers.v23i3.2016

Datta, J., Wei, Q., Yang, Q., Wan, P.J., He, J.C., Wang, W.X., Lai, F.X., Ali MdP., Fu, Q., 2021. Current resistance status of the brown planthopper Nilaparvata lugens (Stål) to commonly used insecticides in China and Bangladesh. Crop Protection. 150. https://doi.org/10.1016/j. cropro.2021.105789

Devonshire, A.L., 1991. Role of esterases in resistance of insects to insecticides. Biochem. Soc. Trans. 19, 756759. https://doi.org/10.1016/S0920-9964(99)000067

Diptaningsari, D., Trisyono, Y.A., Purwantoro, A., Wijonarko, A., 2020. Stability of resistance to imidacloprid in the brown planthopper (Nilaparvata lugens Stål.) from Banyumas, Central Java.Jurnal Perlindungan Tanaman Indonesia. 24, 61-67. https://doi.org/10.22146/ jpti.43954

Directorate of Fertilizers and Pesticides., 2016. Pesticide for Agriculture and Forestry Year 2016. Agricultural ministry of Indonesian.

Dono, D., Ismayana, S., Prijono, D., Idar, Muslikha, I., 2010. Status and biochemical resistance of Crocidolomia pavonana (F.) (Lepidoptera: Crambidae) to organophosphate insecticide and its sensitivity to botanical insecticide. J. Entomol. Indon. 7, 9-27. https://doi.org/10.5994/JEI,7,1,9

Dono, D., Natawigena, W.D., Kharismansyah, H.K., 2014. Resistance status of Crocidolomia pavonana $\mathrm{F}$. (Lepidoptera: Crambidae) from Pasirwangi Garut, West Java to the insecticide profenofos and its susceptibility to the methanolic leaf extract of Nicotiana tabacum L. (Solanaceae). J. ISSAAS. 20, 121130.

Dono, D., Maharani, R., Hidayat, Y., Hartati, S., 2017. Production, standardization, legalization and marketing of botanical insecticide of seed extracts formulation of Azadirachta indica and Barringtonia asiatica.(Research report). Universitas Padjadjaran.

Dvir, H., Silman, I., Harel, M., Rosenberry, T.L., Sussman, J.L., 2010. Acetylcholinesterase: from 3D structure to function. Chem. Biol. Interact. 187, 10-22. https:// doi.org/10.1016/ j.cbi.2010.01.042

Ellman, G.L., Courtney, K.D., Andres, V., Featherstone, R.M. 1961. A new and rapid colorimetric determination of acetylcholinesterase activity. Biochem. Pharmacol. 7, 88-95. https://doi.org/10.1016/0006-2952(61)901459.

Futuko, T., 1990. Mechanism of action of organophosp and carbamate insecticides. Environ. Health Perspect. 87, 245-254. https://doi.org/10.1289/ehp.9087245

George, A., Rao, C.N., Rahangadale, S., 2019. Current status of insecticide resistance in Aphisgossypii and Aphisspiraecola (Hemiptera: Aphididae) under central Indian conditions in citrus. Cogent Biology. 5, 1. https://doi.org/10.1080/23312025.2019.1660494

Georghiou, G.P., 1962. Carbamate insecticides: toxic action of synergized carbamates against twelve resistant strain of the house fly. Journal of Economic Entomology. 55, 768-772. https://doi.org/10.1093/jee/55.5.768
Govindachari, T.R., Suresh, G., Gopalakrishnan, G., Wesley, S.D., 2000. Insect antifeedant and growth regulating activities of neem seed oil-the role of major tetranortriterpenoids. J. Appl. Ent. 124, 287-291. https://doi.org/10.1046/j.1439-0418.2000.00480.x

Habig, W., Pabst, M., Jakoby, W., 1974. Glutation S-Transferase The first enzymatic step in mercapturic acid formation. J. Biol. Chem. 249:7130-7139. https://doi.org/10.1016/ S0021-9258(19)42083-8

Haque, N.M.M., Rabbi, M.F., Karim, A.N.R., Haq, M., Chowdhury, M.A., 2002. Resistance and resurgence studies of neem oil $50 \%$ ec against rice brown planthopper, Nilaparvata lugens. Pakistan J. Biol. Sci. 8, 858-861. https://doi.org/10.3923/pjbs.2002.858.861

Hastutiek, P., Fitri, E., 2002. Resistance of musca domestica to insecticide and its mechanisms. Indones. J. Trop. Med. 1, 1-22.

Heong, K.L., Tan, K.H., Garcia, C.P.F., Fabellar, L.T., Lu, Z., 2011. Research Methods in Toxicology and insecticide resistance Monitoring of Rice Planthoppers. International Rice Research Institute (IRRI)., Metro Manila, Philippines.

Hidayat, A.T.,Zainuddin, A., Dono, D., Hermawan, W., Hayashid, H., Supratman, U., 2014. Synthetic and structureactivity relationship of insecticidal bufadienolides. Natural product communications. 9, 925-927. https:// doi.org/10.1177/1934578X1400900710

[IRAC] Insecticides Resistance Action Committee., 2013. IRAC Susceptibility Test Method 005. URL http://www.iraconline.org/methods/nilaparvata-lugens-nephotettixcincticeps-adults/. [Date accessed: 29 June 2018]

[IRAC] Insecticides Resistance Action Committee., 2021. Irac Mode Of Action Classification Scheme Version 10.1. 2021.

Khan, S., Uddin, M.N., Rizwan, M., Khan, W., Farooq, M., Shah, A.S., Subhan, F., Aziz, F., Ur Rahman, K., Khan, A., Ali, S., Muhammad., 2020. Mechanism of insecticide resistance in insects/pests. Pol. J. Environ. Stud. 29, 2023-2030. https://doi.org/10.15244/pjoes/108513

Le Navenant, A., Siegwart, M., Maugin, S., Capowiez, Y., Raul, M., 2019. Metabolic mechanisms and acetylcholinesterase sensitivity involved in tolerance to chlorpyrifos-ethyl in the earwig Forficula auricularia. Chemosphere. 227, 416-424. https://doi.org/10.1016/j. chemosphere.2019.04.065

Liu, Z., Williamson, M.S., Lansdell, S.J., Denholm, I., Han, Z., Millar, N.S., 2005. From the cover: a nicotinic acetylcholine receptor mutation conferring targetsite resistance to imidacloprid in Nilaparvata lugens (brown planthopper). Proc. Natl. Acad. Sci. 102, 84208425. https://doi.org/10.1073/pnas.0502901102

Lowery, D.T., Smirle, M.J., 2000. Toxicity of insecticides to obliquebanded leafroller, Choristoneura rosaceana larvae and adults exposed previously to neem seed oil. Entomol. Exp. Appl. 95, 201-207. https://doi. org/10.1046/j.1570-7458.2000.00658.x

Maran, E., Fernández-Franzón, M., Font, G., Ruiz, M.J., 2010. Effects of aldicarb and propoxur on cytotoxicity and lipid peroxidation in CHO-K1 cells. Food Chem. Toxicol. 48, 1592-1596. https://doi.org/10.1016/j. fct.2010.03.030

Mardiningsih, T.L., Sukmana, C., Tarigan, N., Suriati, S. 2010. The effectiveness of botanical insecticides of azadirachtin and saponin active ingredients to mortality of Aphis gossypii glover and intensity of attack. Bul. Penelit. Tanam. Rempah dan Obat. 21, 171-183. 
Mordue, A.J., Simmonds, M.S.J. Ley, S.V Blaney, W.M., Mordue, W., Nasiruddin, M., Nisbet, A.J., 1998. Actions of azadirachtin, a plant allelochemical, against insects. Pestic. Sci. 54, 277-284. https://doi.org/10.1002/ (SICI ) 1096-9063(1998110)54:3<277::AIDPS801>3.0.CO;2-I

Mordue (Luntz), A.J., Nisbet, A.J., 2000. Azadirachtin from the neem tree Azadirachta indica: its action against insects. An. da Soc. Entomológica do Bras. 29, 615-632. https://doi.org/10.1590/S0301-80592000000400001

Nan-nan, L., Fang, Z., Qiang, X., Pridgeon, J., Xi-Wu, G., 2006. Behavioral change, physiological modification, and metabolic detoxification: mechanisms of insecticide resistance. Acta Entomol. Sin. 49, 671-679.

Park, H.M., Lee, Y.D., Choi, S.H., 1991. The absorpsion and metabolism of fenobucarb and carbofuran by susceptible and carbamate insekticide selected strains of the brown planthopper Nilaparvata lugens stal. Korean J. Appl. Entomol. 30, 10-17.

Pathak, C.S., Tiwari, S.K., 2017. Potential of neem seed's acetone extract on the haemolymph and fat biochemistry of Cocyra cephalonica larvae (Lepidoptera: Pyralidae).J. Adv. Zool. 38, 164-177.

Plapp, F.W.J., Bigley, W., 1961. Carbamate Insecticides and Ali-esterase activity in insects 1. J. Econ. Entomol. 54, 793-796. https://doi.org/10.1093/jee/54.4.793

Puinean, A.M., Denholm, I., Millar, N.S., Nauen, R., Williamson M.S., 2010. Characterisation of imidacloprid resistance mechanisms in the brown planthopper, Nilaparvata lugens Stål (Hemiptera: Delphacidae). Pestic. Biochem. Physiol. 97, 129-132. https://doi.org/10.1016/ j.pestbp.2009.06.008

Qiao, J., Zou, X., Lai, D., Yan, Y., Wang, Q., Li, W., Deng, S., $\mathrm{Xu}, \mathrm{H} ., \mathrm{Gu}, \mathrm{H} ., 2$ 2014. Azadirachtin blocks the calcium channel and modulates the cholinergic miniature synaptic current in the central nervous system of Drosophila. Pest Manag. Sci. 70, 1041-1047. https:// doi.org/10.1002/ps.3644

Roush, R.T., Miller, G.L., 1986. Consideration for design of insecticide resistance monitoring programs. J. Econ. Entomol. 79, 293-298.

Sanil, D., Shetty, V., Shetty, N.J., 2014. Differential expression of glutathione s-transferase enzyme in different life stages of various insecticide-resistant strains of anopheles stephensi: a malaria vector. $J$. Vector Borne Dis. 51, 97-105. https://doi.org/10.1006/ pest.2001.2549

Siegfried, B.D., Scott, J.G., 1992. Biochemical characterization of hydrolytic and oxidative enzymes in insecticide resistant and susceptible strains of the german cockroach (Dictyoptera: Blattellidae). Journal of Economic Entomology. 85, 1092-1098. https://doi. org/10.1093/jee/85.4.1092 1092-1098

Smina, A.H., Samira, B., Mohamed, D., 2016. Evaluation of acetylcholinesterase, glutathione S-transferase and catalase activities in the land snail Helix aspersa exposed to thiamethoxam.J. Entomol.Zool. Stud.Zool. Stud. 4, 369-374.

Surahmat, E.C., Dadang, Prijono, D., 2016. Susceptibility of the rice brown planthopper (Nilaparvata lugens) from six locations in Java to three insecticides. J. Hama dan Penyakit Tumbuh. Trop. 16, 71-81. https://doi. org/10.23960/j.hptt.11671-81

Suryaningsih, E., Hadisoeganda, A.W., 2007. Control measure for important pests and diseases of hot pepper by applying biorational pesticide.J. Hortik. 17, 261-269. https://doi.org/10.1002/aelm.201400015
Taşkin V., Kücükakyüz, K., Arslan, T., Cöl, B., Taşkin, B.G., 2007. The biochemical basis of insecticide resistance and determination of esterase enzyme patterns by using PAGE in field collected populations of Drosophila melanogaster form Muğla Province of Turkey. J. Cell Mol. Biol. 6, 31-40.

Tan, J., Salgado, V., Hollingwoth, R., 2008. Neural action of imidacloprid and their involvement in resistance in the corolado potato beetle, Leptinotarsa decemlineata (Say). Pest Manag. Sci. 64, 37-47. https://doi. org/10.1002/ps

Tarwotjo, U., Rahadian, R., 2018. The role of acetylcholine esterase in resistance mechanism of Plutella xylostella to emamektin benzoate. Biosaintifika J. Biol. Biol. Educ. 10, 66-71. https://doi.org/10.15294/biosaintifika. v10i1.13955

Toumi, H., Bejaoui, M., Touaylia, S., Burga, Perez, K.F., Ferard, J.F., 2016 Effect of carbaryl (carbamate insecticide) on acetylcholinesterase activity of two strains of Daphnia magna (Crustacea, Cladocera). J. Environ. Sci. Heal. Part B Pestic. Food Contam. Agric. Wastes. 51, 777-780. https://doi.org/10.1080/03601234.2016.1198645

Vontas, J.G., Small, G.J, Hemingway, J., 2001. Glutathione S-Transferases as antioxidant defence agents confier pyretroid resistance in Nilaparvata lugens. Biochem. J. 357, 65-72. https://doi.org/10.1042/bj3570065

Wang, Y.H., Gao, C.F., Zhu, Y.C., Chen, J., Li, W.H., Zhuang, Y.L., Dai de, J., Zhou, W.J., Yong, C., Shen, J.L., 2008. Imidacloprid susceptibility survey and selection risk assessment in field populations of Nilaparvata lugens (Homoptera: Delphacidae).J. Econ. Entomol. 101:515522. https://doi.org/10.1603/0022-0493(2008)101

Wang, Y.H., Wu, S.G., Zhu, Y.C., Chen, J., Liu, F.Y., Zhao, X.P., Wang, Q., Li, Z., Bo, X.P., Shen, J.L., 2009. Dynamics of imidacloprid resistance and cross-resistance in the brown planthopper, Nilaparvata lugens. Entomol. Exp. Appl. 131, 20-29. https://doi.org/10.1111/j.15707458.2009.00827.x

Winteringham, F.P.W., 1969. FAO international collaborative programme for the development of standardized test for resistance of agricultural pests to pesticides. FAO Plant Prot Bull. 17, 73-75.

Yoo, J.K., Lee, S.W., Ahn, Y.J., Nagata, T., Shono, T., 2002. Altered acetylcholinesterase as a resistance mechanism in the brown planthopper (Homoptera: Delphacidae), Nilaparvata lugens Stal. Appl. Entomol. Zool.37, 37-41. https://doi.org/10.1303/aez.2002.37

Yu, S.J., Nguyen, S.N., Abo-Elghar, G., 2003. Biochemical characteristics of insecticide resistance in the fall armyworm, Spodoptera frugiperda (J. E. Smith) q. Pestic. Biochem. Physiol. 77, 1-11. https://doi. org/10.1016/S0048-3575(03)00079-8

Zewen, L., Zhaojun, H., Yinchang, W., Lingchun, Z., Hongwei, Z., Chengjun, L., 2003. Selection for imidacloprid resistance in Nilaparvata lugens: cross-resistance patterns and possible mechanisms. Pest Manag. Sci. 59, 1355-1359. https://doi.org/10.1002/ps.768

Zhang, X., Liu, X., Zhu, F., Li, J., You, H., Lu, P., 2014. Field evolution of insecticide resistance in the brown planthopper (Nilaparvata lugens Stål) in China. Crop Prot. 58, 61-66. https://doi.org/10.1016/j. cropro.2013.12.026 